\title{
The Effect of Capsaicin on the Viability and Angiogenesis of Random-Pattern Skin Flaps
}

\author{
(1) Mehmet Ersin Gönüllü, ${ }^{1}$ (1) Çağla Çiçek, ${ }^{2}$ (1) Emre Güvercin, ${ }^{2}$ \\ (1) Gaye Filinte, ${ }^{2}$ (1) Deniz Filinte ${ }^{3}$
}

\footnotetext{
${ }^{1}$ Department of Plastic, Reconstructive and Aesthetic Surgery, M. Ersin Gönüllü Private Clinic, İstanbul, Turkey ${ }^{2}$ Department of Plastic Reconstructive and Aesthetic Surgery, University of Health Sciences, Kartal Dr. Lütfi Kırdar Training and Research Hospital, İstanbul, Turkey ${ }^{3}$ Department of Pathology, Marmara University, Pendik Training and Research Hospital, İstanbul, Turkey

Submitted: 27.03 .2020 Accepted: 05.06.2020

Correspondence: Çağla Çiçek SBÜ Kartal Dr. Lütfi Kırdar Eğitim ve Araştırma Hastanesi Plastik Rekonstrüktif ve Estetik Cerrahi Kliniği, İstanbul, Turkey E-mail:

caglamutkan2002@yahoo.com

Keywords: Angiogenesis of
flap; capsaicin;
viability of flap.
(6) $\mathbf{0} \mathbf{O}$
Attribution-Noncommercial 4.0 International License.
}

\begin{abstract}
Objective: Random flaps are often the first choice of technique in plastic surgery, however, necrosis developing in the distal portion of the flap during angiogenesis may necessitate additional surgery. Prolonged treatment is expensive in terms of labor, time, and morale. Several drugs have been investigated as a means of improving the viability of random flaps, and while satisfactory results have been reported, potential side effects due to systemic use and high costs have prevented widespread clinical use. This study examined capsaicin as a resource for improved viability and angiogenesis in random flaps.
\end{abstract}

Methods: Random-pattern, dorsal, McFarlane skin flaps were created in 60 male Wistar albino rats weighing $180-230 \mathrm{~g}$ (experimental group: $n=30$; control group: $n=30$ ) and sutured back into place. Capsaicin $0.1 \%$ cream was applied on the flap postoperatively and topically twice daily for 7 days in the experimental group. The necrosis rate was calculated using Sasaki's paper template method.

Results: The ratio of the necrotic portion of the flap to the total flap was $22.9 \pm 8.94 \%$ in the experimental group and $36.8 \pm 10.05 \%$ in the control group. Analysis of polymorphonuclear leukocyte infiltration, lymphocyte ratio, capillary proliferation, and other parameters indicated that the application of capsaicin cream had a positive effect on flap viability in some zones in the experimental group.

Conclusion: Significantly less necrosis was seen in the experimental group. The results suggest that capsaicin $0.1 \%$ cream may increase the viability of random pattern skin flaps. However, differences in transdermal application characteristics between species, between individuals, and even between regions in a single individual demonstrate the need for additional studies.

\section{INTRODUCTION}

Although the simplest option for closing a defect in plastic, reconstructive and aesthetic surgery is still sometimes the first choice, accumulative knowledge and developments in microsurgical techniques and technology have permitted the more frequent use of more advanced applications at the top of the reconstructive ladder. Both functional integrity and aesthetic results can be achieved in soft tissue reconstruction using the principle of "similia similibus curantur," or "like cures like." However, random pattern flaps remain the first choice in centers with no microsurgery unit or when free tissue transplantation is not suitable for the patient. There is substantial re- search on the anatomical and physiological behavior of these flaps. Blood flow is provided by the subdermal and subfascial plexuses in random pattern flaps, since there is no major artery supplying the flap. ${ }^{[1]}$ The viability of a flap has been thought to be contingent on the size of the flap and the distance from the pedicle. A ratio of the pedicle width to flap length has been generally been applied, with variations according to region. ${ }^{[2]}$ Partial or complete flap necrosis is still a problem despite new flap designs developed as a result of recent anatomical studies and more information on angiosomes. ${ }^{[3]}$ The presence of necrosis will increase the length of hospital stay, number of operations, costs, and psychological vulnerability of the patient. Many pharmacological agents have been identified 
that increase flap viability in random pattern flaps, and methods such as staggering subsequent procedures have also been used. Surgical delay increases the flap survival, however, a two-stage surgical procedure also creates disadvantages. Pharmacological agents can have various side effects when administered systemically, and sometimes high doses are needed to achieve the intended effect. ${ }^{[4]}$ In order to avoid side effects, locally effective agents have also been used experimentally to improve flap viability. Chili pepper, which is consumed as a spice in many parts of the world, is also widely used in medicine. Chili peppers contain the capsaicinoid compounds of capsaicin, nordihydrocapsaicin, homodihydrocapsaicin, dihydrocapsaicin and homocapsaicin. The principal capsaicinoids of capsaicin and dihydrocapsaicin have twice the effect of the minor capsaicinoids (nordihydrocapsaicin, homodihydrocapsaicin, and homocapsaicin). ${ }^{[5]}$ The results of various studies have shown that capsaicin in various pharmaceutical forms can be used to alleviate neuropathic pain; provide symptomatic treatment of arthritis, muscle and joint pain; and treat neurogenic pain such as herpes zoster, as well as ulcers and obesity. ${ }^{[6]}$ Capsaicin increases vascularization and accelerates metabolism where it is applied topically due to hyperemia and generating heat on the skin. Based on this effect and a potentially beneficial influence on flap viability, this study was designed to examine results of capsaicin use on the viability and angiogenesis of random pattern skin flaps in rats.
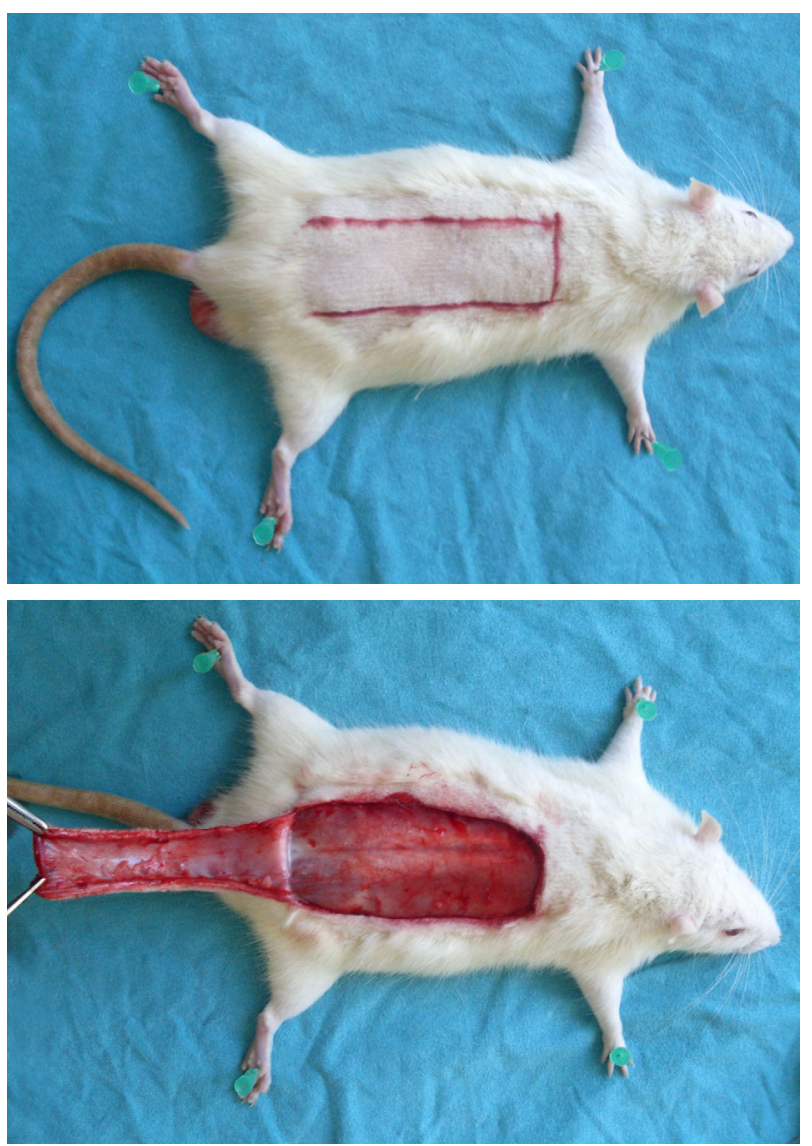

Figure 1. The flap design of study.

\section{MATERIALS AND METHODS}

The Pendik Veterinary Control Institute, Experimental Animals Department and the local ethics committee granted approval of the research proposal (date: 06.03.2012, desicion no: 07/2012). Sixty male Wistar albino rats weighing $180-230 \mathrm{~g}$ were divided into a control group $(n=30)$ and an experimental group $(n=30)$. A rectangular, $3 \times 9 \mathrm{~cm}$ Khouri-modified MacFarlane flap with a caudal base and random pattern circulation was created on the back of the subjects. In the experimental group, the flap was elevated, a topical application of $0.1 \%$ capsaicin cream was administered, and the flap was replaced in the original location. No treatment was applied to the control group before flap repositioning and suturing.

All of the animals were provided with standard room conditions. The temperature was fixed at $18-20^{\circ}$ and 12 hours of darkness and 12 hours of light were provided. The rats were housed individually for safety. Standard rat feed and access to tap water were provided ad libitum. General anesthesia was administered intramuscularly with a combination of ketamine $30 \mathrm{mg} / \mathrm{kg}$ and $0.5 \mathrm{mg} / \mathrm{kg} x y-$ lazine. The depth of anesthesia was evaluated based on the nociceptive withdrawal reflex. After the animals were asleep, they were positioned face down on the surgical table and all of the extremities were fixed. The surgical area was prepared with an electric razor. Both iliac bones were identified by palpation and marked. The flap base was



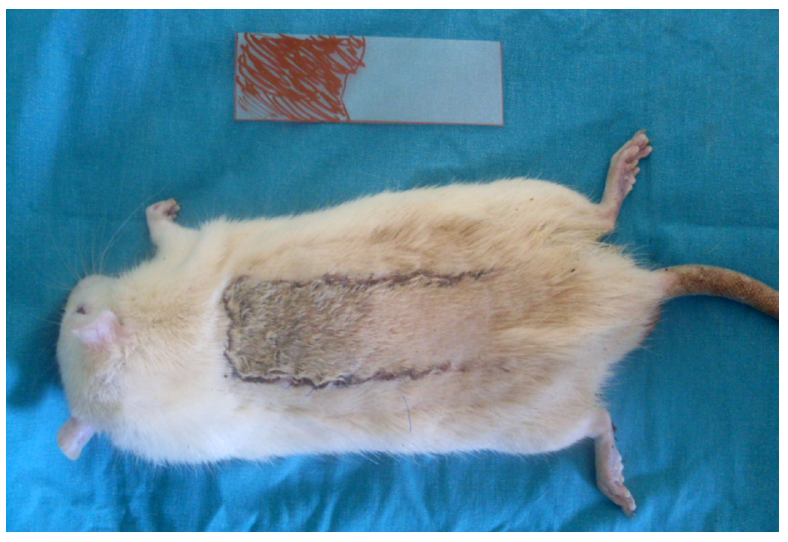

Figure 2. Demarcation of the flap size and necrosis line.

defined as a line between the marked iliac bones. A $3 \times 9 \mathrm{~cm}$ marker previously prepared on acetate paper was used to delineate the flap, which was elevated by sharp dissection from the deep fascia and included the panniculus carnosus in the base. The elevated flaps were subsequently replaced in the donor site (Fig. I).

\section{Clinical evaluation}

The flaps were monitored for 7 days and evaluated daily for necrosis. Areas of epidermolysis were later included in the living flap area as they recovered through epithelialization. On day 7, Sasaki's paper template method was used to evaluate the percentage of flap necrosis and calculate flap viability percentages. The flap size and necrosis line were drawn on transparent acetate paper with an acetate pen (Fig. 2). The total flap area was demarcated, and then the dimensions of the necrotic portion were measured. The necrotic flap area/total area ratio was evaluated as a percentage. The flap survival area was calculated using AutoCad image analysis software (Autodesk Inc., San Rafael, CA, USA).

\section{Histopathological assessment}

On the seventh day, necrotic tissue, living tissue, and tissue from the transition zone between those areas were fixed in $10 \%$ formalin and embedded in paraffin blocks. Four- $\mu \mathrm{m}-$ thick sections were taken from the embedded tissue and stained with hematoxylin and eosin and trichrome dyes. The sections were examined by a single pathologist under a light microscope and were scored according to capillary proliferation, polymorphonuclear leukocyte (PMNL) and lymphocyte infiltration, fibroblast increase, collagen densi- ty, and edema parameters (Table I).

\section{Statistical analysis}

The SPSS (Statistical Package for Social Sciences) was used to perform the statistical analysis. A post hoc chi-squared analysis was applied to determine categories of statistically significant difference. The histopathological findings were evaluated according to significance levels obtained using the Bonferroni correction. The Mann-Whitney $U$ analysis was used to compare the ratio of the area of the necrotic portion of the flap to the entire flap area in the experimental and control groups. The statistical significance level was $\alpha=0.80$ and $p<0.05$ for reliability.

\section{RESULTS}

The mean ratio of the necrotic part of the flap to the total flap in the experimental group was $22.9 \pm 8.94 \%$ and the median was $21.5 \%$. The ratio of the necrotic portion of the removed flap to the total flap in the control group was $36.8 \pm 10.05 \%$ and the median was $40.5 \%$. This difference was statistically significant $(p<0.05)$. The PMNL infiltration in the dermis and panniculus carnosus of the flaps was compared between groups and it was determined that the intervention in the experimental group resulted in significantly decreased PMNL infiltration in the necrosis zone in the dermis compared with the control group $(p<0.00 \mathrm{I})$. The capsaicin applied in the experimental group also decreased the lymphocyte ratio significantly $(p=0.02 \mathrm{I})$, but there was no significant difference in the lymphocyte infiltration between zones. When the lymphocyte infiltration in the panniculus carnosus was compared in the experimental group and the control group, no significant statistical significance was found between the 2 groups or between zones ( $p>0.05)$. Analysis of the capillary proliferation in the dermis of the flaps revealed that capillary proliferation was significantly greater in the necrotic zone in the experimental group $(p<0.001)$. No significant change was observed in any zone of the panniculus carnosus when compared with the control group. Comparison of the fibroblast and collagen density in the dermis of the flaps in the experimental and control group rats indicated that the fibroblast density was statistically significantly greater in the normal and transition dermis compared with the control group. However, this statistically significant increase could only be detected in the transition zone of the panniculus carnosus $(p<0.00 I)$. In the comparison of the flaps

Table I. Pathological examination of samples

\begin{tabular}{|c|c|c|c|c|}
\hline PMNL/Lymphocyte infiltration & Capillary vessel proliferation & Quantity of fibroblasts & Quantity of collagen & Edema \\
\hline 0: Normal & $0:$ None & I:None & 0: Decreased & 0: None \\
\hline I: Moderate & I: Mild & 2: Mild & I: Normal & I: Mild \\
\hline 2: Severe & $\begin{array}{c}\text { 2: Moderate } \\
\text { 3: Severe }\end{array}$ & 3: Severe & 2: Increased & 2: Severe \\
\hline
\end{tabular}


of the experimental group and the control group rats in terms of dermis and panniculus carnosus edema, it was found that the topically applied capsaicin reduced dermis edema only in the normal zone $(p=0.008$ and $p=0.02$, respectively), and there was no contribution to edema reduction in the necrotic zone or the transition zone.

\section{DISCUSSION}

The success rate of free tissue flaps, which have extensive applications, has exceeded $90 \%$. It has been reported that partial or complete flap loss and complications in pedicled flaps increase up to $25 \% .^{[7]}$ Randomized pattern flaps provide a solution for centers with insufficient microsurgical teams and equipment and in cases where free tissue transfer cannot be performed due to the general condition of the patient. However, partial or complete flap loss is still an important problem in random pattern flaps. This consequence increases the number of operations, lengthens hospital stay, and adds to distress and economic loss. Thus, anatomical and physiological behavior patterns of random pattern flaps have been the subject of many studies in an effort to increase flap survival. Better understanding of flap physiology and flap loss mechanisms led to studies examining how to increase blood flow to a flap and methods to prevent reperfusion damage after ischemia. The quantity of blood flow entering the flap is the most important factor determining random flap viability. ${ }^{[1]}$ Macrocirculation has been examined as a means to increase blood flow to a flap without changing the existing vascular network of the flap. Various vasodilator agents have been used for this purpose and the research results have been promising, but none of the agents have yet found a place in clinical practice. ${ }^{[8]}$ Another means to increase flap blood flow is to create a new vascular network outside the flap's own network, known as neoangiogenesis. ${ }^{\left[{ }^{[9}\right.}$ Experimental studies of numerous systemic and topical agents have been conducted to investigate a means of providing neoangiogenesis within the flap, but are not yet used in daily practice.

In our study, the statistical analysis indicated that the quantity of PMNL infiltration was greater in the dermis in control group, while it was greater in the experimental group in the transition and necrotic area of the panniculus carnosus. However, no significant difference was found between the control and experimental groups in any zones of the dermis and panniculus carnosus. This suggests that capsaicin did not make a clear difference in the acute and chronic inflammation process of the flap. During microscopic examination of the capillary proliferation level, the amount of dermal capillary in the necrotic region was greater in the experimental group, while there was no significant difference in the other regions or the panniculus carnosus. It appeared that capsaicin contributed to the increase in the dermal capillary process. The fibroblast and collagen levels were significantly higher in the dermis and panniculus carnosus, especially in the transition regions, in the experimental group. This suggests that capsaicin af- fected the balance of metabolism in the flap in favor of production. There was no clear difference between the quantity of acute and chronic inflammatory cells. Increased capillary, fibroblast, and collagen densities and decreased edema in some zones in the experimental group indicated that capsaicin cream positively affected flap viability and flap metabolism. As a result, topical capsaicin cream is thought to be beneficial in terms of increasing flap viability. Rats are the first choice for studies using topical agents due to less individual transdermal absorption difference and the similarity of the skin structure to that of humans. ${ }^{[10]}$ Rat skin is 2 times more permeable than human skin as a result of membrane lipophilicity, dermis and epidermal thickness, and hair follicle density on the surface. ${ }^{\left[{ }^{\prime \prime}\right]}$ Our study is preliminary, and differences in absorption between species should be taken into consideration for clinical practice. The most reliable results in studies of transdermal applications can be achieved with human subjects, however, transdermal absorption in humans varies considerably from one person to another, and even between regions in the same individual. Therefore, standardization of results is difficult. ${ }^{[10]}$

\section{CONCLUSION}

No method can prevent flap loss that results due to incorrect planning or insufficient arterial input. However, the necrosis rate in flaps can be reduced by strengthening the arterial architecture and metabolic activity in the flap. In our study, it was determined that capsaicin $0.1 \%$ cream increased vascularity and metabolism and increased flap viability. Capsaicin is easy to obtain and use, and topical application avoids the side effects that may occur with systemic treatments. However, further studies are needed to assess differences in the effects of transdermal application between species, between individuals, and even between regions in the same individual.

\section{Ethics Committee Approval}

Approved by the local ethics committee (date: 06.03 .2012 , desicion no: 07/2012).

Peer-review

Internally peer-reviewed.

Authorship Contributions

Concept: G.F.; Design: G.F., E.G.; Supervision: G.F.; Fundings: M.E.G., D.F;; Materials: M.E.G., D.F.; Data: M.E.G.; Analysis: G.F.; Literature search: Ç.Ç.; Writing: Ç.Ç.; Critical revision: G.F.; Ç.Ç.

Conflict of Interest

None declared.

\section{REFERENCES}

1. Poole MD. The arterial anatomy of skin flaps By George C. Cormack and B. George H. Lamberty. 1986. Churchill Livingstone. pp. 455. Price $£ 125.00$. British Journal of Oral and Maxillofacial Surgery 1987;25:439. 
2. Vedder NB. Flap physiology. In: Mathes SJ, Hentz VR, editors. Plastic Surgery Vol. 1. 2nd ed. Philadelphia: Sander Elsevier; 2006. p. 483-506.

3. Huemer GM, Wechselberger G, Otto-Schoeller A, Gurunluoglu R, Piza-Katzer H, Schoeller T. Improved dorsal random-pattern skin flap survival in rats with a topically applied combination of nonivamide and nicoboxil. Plast Reconstr Surg 2003;111:1207-11.

4. Raposio E; Santi PL. Pharmacological enhancement of cutaneous flap survival with topical dimethyl sulphoxide and hydrogen peroxide. British journal of plastic surgery 1998;51:551-4.

5. Thomas BV, Schreiber AA, Weisskopf CP. Simple method for quantitation of capsaicinoids in peppers using capillary gas chromatography. Journal of agricultural and food chemistry 1998;46:2655-63.

6. Sener E, Şahin S. Farmakokinetik, toksikolojik ve farmakolojik özel- likleri. J Pharm Fac Hacettepe Univ 2010;29:149-63.

7. Bakhach J. 1984-1994: Ten years of skin flaps. Recent advances in experimental surgery. [Article in French]. Ann Chir Plast Esthet 1995;40:583-95.

8. Rohrich RJ, Cherry GW, Spira M. Enhancement of skin-flap survival using nitroglycerin ointment. Plast Reconstr Surg 1984;73:943-8.

9. Takeuchi H, Mano Y, Terasaka S, Sakurai T, Furuya A, Urano H, et al. Usefulness of rat skin as a substitute for human skin in the in vitro skin permeation study. Exp Anim 2011;60:373-84.

10. Nieto CS, Garcia MJS; Garcia PB. A comparative study on the effect of various pharmacological agents on the survival of skin flaps in the rat. British journal of plastic surgery 1992;45:113-6.

11. Jakasa I, Kezic S. Evaluation of in-vivo animal and in-vitro models for prediction of dermal absorption in man. Human $\&$ experimental toxicology 2008;27:281-8.

\section{Kapsaisin'in Random Paternli Cilt Fleplerinin Yaşayabilirliğinde ve Anjiogenezi Üzerindeki Etkisi}

Amaç: Random paternli cilt flepleri sıklıkla plastik cerrahi pratiğinde ilk tercih edilen fleplerdir, ancak flebin angiogenezi sırasında distal kısmında meydana gelen nekroz ek cerrahilere ihtiyaç duyulmasına sebep olur. Tedavinin uzaması iş gücü, zaman ve moral açısından maliyetlidir. Random paternli cilt fleplerinin yaşayabilirliğinin arttırılması için birçok ilaç araştırılmıştır ve bunların etkileri ile ilgili her ne kadar tatmin edici sonuçlar elde edilmiş olsa da; bu ilaçların sistemik kullanımına ve yüksek maliyetine bağı potansiyel yan etkiler klinik kullanımlarını kısıtlamıştır. Bu çalışmada, random paternli cilt fleplerinin yaşayabilirliğinin arttırılması için kapsaisinin etkisi çalışılmıştır.

Gereç ve Yöntem: 60 adet, I80-230 gr ağılığındaki erkek Wistar Albino sıçan sırtında (deney grubu: $n=30$; kontrol grubu: $n=30$ ) random paternli McFarlane cilt flepleri oluşturuldu ve ardından yerine iade edildi. Deney grubundaki fleplere 7 gün süreyle postoperatif dönemden başlayarak ve topikal olarak günde 2 kez kapsaisin \%0, I krem uygulandı. Fleplerdeki nekroz oranı Sasaki'nin 'papertemplate' yöntemi ile değerlendirildi.

Bulgular: Deney grubundaki fleplerin nekrotik kısmının total flebe oranı \%22.9 $\pm \% 8.94$ iken kontrol grubunda \%36.8 $\pm \% 10.05$ olarak tespit edildi. Polimorfonükleer lökosit infiltrasyonu, kapiller proliferasyon, lenfosit oranı ve diğer parametrelerin analizi; deney grubunda kapsaisin krem uygulanmasının flep yaşayabilirliğine pozitif etkisi olduğunu göstermiştir.

Sonuç: Deney grubunda flep distalinde önemli ölçüde daha az nekroz gözlendi. Elde edilen sonuçlara göre \%0.I'lik kapsaisin kremin topikal uygulanması ile random paternli cilt fleplerinde flep yaşayabilirliğinin arttığı tespit edildi. Ancak bireyler arasında, türler arasında ve aynı bireyde uygulanan bölgeler arası oluşan farklııklar, klinik kullanım için daha geniş çalışmaların yapılması gerekliliğini ortaya koymaktadır.

Anahtar Sözcükler: Flep anjiogenezi; flep yaşayabilirliği; kapsaisin; random paternli cilt flebi. 